\title{
NOTE
}

\section{RETROACTIVITY, HABEAS CORPUS, AND THE DEATH PENALTY: AN UNHOLY ALLIANCE}

\author{
KARL N. METZNER
}

[E]very Member of this Court has written or joined at least one opinion endorsing the proposition that because of its severity and irrevocability, the death penalty is qualitatively different from any other pumishment, and hence must be accompanied by unique safeguards to ensure that it is a justified response to a given offense. ${ }^{1}$

Although the Supreme Court has added four new Justices since this case was decided, ${ }^{2}$ a majority of the Court reaffirmed this fundamental principle on the last day of its most recently completed Terin. ${ }^{3}$ Despite this, the Supreme Court made no distmction between capital and noncapital pumshment as it developed a radical new doctrine for the consideration of habeas corpus petitions: ${ }^{4}$ If the petitioner seeks to benefit from a Supreme Court decision that remterprets the constitutional safeguards required for a fair trial (i.e., seeks to use a "new rule") 5 and that was decided after the petitioner's case was finalized, his case will not be heard in part).

1. Spaziano v. Florida, 468 U.S. 447, 468 (1984) (Stevens, J., concurring in part and dissenting

2. Justice Scalia was appointed to the Supreme Court in 1986, Justice Kennedy in 1988, Justice Souter in 1990, and Justice Thomas in 1991.

3. See Harmelin v. Michigan, 111 S. Ct. 2680, 2702 (1991). The five Justices constituting the majority for this section of the opinion included Chief Justice Rehnquist and Justices O'Connor, Scalia, Kennedy, and Souter-often considered the "conservatives" of the Court.

4. See Penry v. Lynaugh, 492 U.S. 302, 313-14 (1989). A leading treatise on federal jurisdiction explains the nature of habeas corpus (the "Great Writ"):

A litigant in a state court generally may secure federal court review of the state court's judgments and proceedings only by first exhausting all available appeals within the state system and then seeking review of the final judgment in the United States Supreine Court. Federal district courts lack the authority to hear appeals from state judicial systems. However, federal courts have the authority to review state court criminal convictions pursuant to writs of habeas corpus. Under federal law, a person who claims to be held in custody by a state government in violation of the Constitution, treaties, or laws of the United States may file a civil lawsuit in federal court seeking a writ of habeas corpus. Technically, federal court consideration of the habeas corpus petition is not considered a direct review of the state court decision; rather, the petition constitutes a separate civil suit filed in federal court and is termed collateral relief. Pursuant to a writ of habeas corpus the federal court may order the release of a state prisoner who is held by the state in violation of federal law.

ERWIN CHEMERINSKY, Federal JURISDiction § 15.1, at 677-78 (1989) (footnote omitted).

5. See infra text accompanying notes $24-29$ for an explanation of the "new rule" definition. 
on the merits unless he falls within one of two exceptions. ${ }^{6}$ Even though the doctrine was initially developed in a non-capital case, ${ }^{7}$ the Court nevertheless applied it to a capital case in which it was implicated without any alteration or discussion. ${ }^{8}$ Three cases in the Court's subsequent Term furtlier refined the doctrine, ${ }^{9}$ thereby establishing the applicable law for federal habeas corpus cliallenges to state-imposed death sentences. Althougl one may argue that the newly developed doctrime is unwise and unfair in all contexts, its application to capital sentencing is particularly egregious in light of the unique nature of the death penalty. ${ }^{10}$ This Note argues that the Supreme Court, when applying its new doctrine to capital cases, moved too hastily and failed to consider the qualitative distinction between capital and non-capital punishment. The Court should therefore amend its new doctrine in the capital sentencing context.

In its 1989 Term, the Supreme Court affirmed three death sentences that suffered from constitutional flaws that would liave normally constituted reversible error. ${ }^{11}$ Unfortunately for the criminal defendants involved, the Court did not consider their claims on the merits because of the procedural posture of their cases. All three challenged their sentences through federal habeas corpus proceedings, an avenue that liad been used effectively by other death-row inmates on numerous previous occasions. ${ }^{12}$ These petitioners, however, were unable to have their claims lieard because they were the victims of a new Supreme Court doctrine relating to labeas corpus proceedings: A federal court will refuse to consider the defendant's claim on the merits unless certain stringent criteria pertaining to retroactivity are met. This new doctrine promises to im-

6. See infra text accompanying notes $32-39$ for an explanation of these exceptions.

7. See Teague v. Lane, 489 U.S. 288 (1989).

8. See Penry, 492 U.S. at 313-14.

9. Butler v. McKellar, 110 S. Ct. 1212 (1990); Saffle v. Parks, 110 S. Ct. 1257 (1990); Sawyer v. Smith, 110 S. Ct. 2822 (1990).

10. This Note focuses on federal habeas corpus review of state-imposed death sentences, not on review of the substantive guilt or innocence of the defendant. Under most state procedures, offenses that carry the possibility of a death sentence are tried in two phases (bifurcated). First, the defendant's guilt or innocence is determined. Then, having been found guilty, a second proceeding (usually before the same jury, sometimes before the judge alone, depending on the state) determines whether the defendant shall be sentenced to death. See, e.g., CaL. Pennal CODE $\S 190.1$ (West 1988); N.C. Gen. Stat. § 15A-2000 (1988); Tex. Code Crim. Proc. ANN. art. 37.071 (West Supp. 1991); see also Marshall v. Lonberger, 459 U.S. $422,456 \mathrm{n} .8$ (1982) (citing states with this system). This Note concentrates on appeals from death sentences imposed in the second phase of capital trials.

11. Butler v. McKellar, 110 S. Ct. 1212 (1990); Saffle v. Parks, 110 S. Ct. 1257 (1990); Sawyer v. Smith, 110 S. Ct. 2822 (1990).

12. See, eg., Maynard v. Cartwright, 486 U.S. 356 (1988); Sumner v. Shuman, 483 U.S. 66 (1987). 
pact adversely the abihty of death-row inmates to attack collaterally their convictions and sentences through federal habeas corpus.

The Rehnquist Court in Teague v. Lane ${ }^{13}$ heralded a new approach toward federal habeas corpus, one that will hikely become more firmly entrenched with the replacement of Justice Brennan with Justice Souter, ${ }^{14}$ and the replacement of Justice Marshall with Justice Thomas. The Teague doctrine involves retroactive application of Supreme Court decisional law to cases presented on collateral review (i.e., habeas corpus). The basic question of Teague is simple to articulate: Should prisoners who are properly convicted under a previous regime of constitutional interpretation be permitted, on collateral review, to benefit from a favorable change in that interpretation? The answer goes to the center of the debate over the purpose of the writ of habeas corpus and the desire for a defimitive end to individual prosecutions. If one believes, as do the dissenters in the cases that follow, that the purpose of habeas corpus is to correct constitutionally flawed convictions or sentences, the answer is a resounding "yes"-if at any time a person has been convicted under what is later determined to have been unconstitutional circumstances, habeas rehef should be available to that person. If, however, one agrees with the current Court majority that the primary role of habeas review is to police the states and prevent unconstitutional practices by those states, the answer is "no"-retroactive application of decisional law on habeas review cannot possibly affect state conduct because at the time of the conviction, the states were operating within the dictates of the Constitution as it was then interpreted. This debate lies at the heart of Teague. ${ }^{15}$ The result of Teague and its progeny is the creation of a general rule against retroactive apphication of new decisional law to cases presented on collateral review, subject to two limited exceptions. As one might expect, the scope and breadth of these exceptions provide the current battleground.

13. 489 U.S. 288 (1989).

14. Although one can never predict with certainty the way a particular Justice will decide a particular issue, Justice Souter's position can be anticipated with some confidence. The Court's new retroactivity doctrine is based upon two of the second Justice Harlan's opinions, see infra text accompanying notes $29-43$, and one of the few definitive positions that Justice Souter was willing to take during his Senate confirmation hearings was that he was a devotec of Justice Harlan's judicial philosophy. See Nomination of David H. Souter to be Associate Justice of the Supreme Court of the United States: Hearings Before the Senate Comm. on the Judiciary, 101st Cong., 2d Sess. 53, 56 (1990). Thus, it is likely that Justice Souter will embrace the reasoning of his judicial hero in this area. However, the Teague doctrine as adopted by the Court was not wholly faithful to Justice Harlan's opinions; Justice O'Connor significantly modified and limited certain aspects of Justice Harlan's approach. See Teague, 489 U.S. at 313. Justice Souter might therefore agree with Justice Stevens, who would have remained faithful to Justice Harlan's original construction. See id. at 31819 (Stevens, J., concurring in part and in judgment).

15. See Teague, 489 U.S. at 308-10; id. at $327-28$ (Brennan, J., dissenting). 
This Note examines the Teague retroactivity doctrine as it applies to capital cases and suggests a modified approacli that would both satisfy the ends sought by the doctrine's supporters on the Court and provide for more meaningful collateral review of deatli sentences. The argument proceeds from the premise, well-supported by numerous opmions written or joined in by nearly every current Justice, that the deatli penalty is qualitatively different from any other form of punishment, and that it deserves sucli treatment in this arena as well. Toward that end, however, the Court need not totally abandon the Teague doctrime, but needs simply to allow for a more flexible application in the capital sentencing context. Furtlier, niany of the ends sought to be establislied by judicial limitation on labeas review of death sentences have already been met in otler contexts, and should not motivate decisions made in this area.

Part I of this Note details the birtl of the new doctrine in Teague $v$. Lane, and Part II discusses its subsequent application to capital sentencing cases in Penry v. Lynaugh. Part III details tlie three major decisions of the following Tern, which define and limit the Teague doctrine. Part IV sets forth the argument for disparate treatment of capital cases. Finally, Part V presents a modification of the current retroactivity doctrine for capital cases.

\section{The Supreme Court's New Retroactivity Doctrine}

Teague v. Lane 16 lias been lieralded as "one of the Supreine Court's most important liabeas corpus decisions in decades." 17 In Teague, Frank Teague collaterally attacked his state conviction for attempted murder on the grounds, inter alia, that the prosecuting attorney intentionally excluded blacks froin his petit jury, thereby violating his Sixtli Amendment rights. ${ }^{18}$ Before considering the merits of Teague's claim, liowever, a

16. 489 U.S. 288 (1989).

17. ChemerinsKy, supra note $4, \S 15.5 .4$, at 129 (Supp. 1990). Because the focus of this Note is on later application of the Teague doctrine in capital cases, the discussion of Teague is somewhat abbreviated in favor of those subsequent cases. However, Teague did generate a substantial amount of literature, and the interested reader may look to some of the following articles for a more substantial analysis and criticism of the case. See, e.g., Joseph L. Hoffman, Retroactivity and the Great Writ: How Congress Should Respond to Teague v. Lane, 1990 B.Y.U. L. REv. 183; Joseph L. Hoffman, The Supreme Court's New Vision of Federal Habeas Corpus for State Prisoners, 1989 SUP. CT. REv. 165 [hereinafter Hoffman, New Vision]; Ellen E. Boshkoff, Note, Resolving Retroactivity after Teague v. Lane, 65 IND. L.J. 651 (1990); Roger D. Branigin III, Comment, Sixth Amendment-The Evolution of the Supreme Court's Retroactivity Doctrine: A Futile Search for Theoretical Clarity, $80 \mathrm{~J}$. CRIM. L. \& C. 1128 (1990); Eliot F. Krieger, Comment, The Court Declines in Fairness, 25 Harv. C.R.-C.L. L. REv. 164 (1990); Note, Federal Jurisdiction and Procedure: Habeas Corpus Collateral Attack on State Criminal Convictions, 103 HARV. L. REv. 290 (1989).

18. Teague, 489 U.S. at 293 . One of the more academically annoying aspects of the decision was that it squarely presented, and yet declined to address, a question that the Court had managed to avoid since Batson v. Kentucky, 476 U.S. 79 (1986), and that held great interest to the criminal law 
plurality of the Supreme Court, led by Justice O'Connor, decided that the case presented an excellent opportumity to rethink and to reformulate the current approach to retroactivity im habeas corpus proceedings. ${ }^{19}$ Thus, the plurality proceeded to discard the prior approach to retroactivity $^{20}$ in favor of a new formulation.

As an initial matter, the plurality acknowledged that the retroactivity issue had been neither raised nor briefed by either party in the case; indeed, the only suggestion that the Court rethink its position came from an amicus brief filed by the Criminal Justice Legal Foundation. ${ }^{21}$ Yet the Court seemed unconcerned by the lack of discussion, stating that "our sua sponte consideration of retroactivity is far from novel."22 The plurality then expressly adopted the relatively uncontroversial position that "the question '[of] whether a decision announcing a new rule should be given prospective or retroactive effect should be faced at the time of that decision." "23 However, the Court went on to assert that "[r]etroactivity is properly treated as a threshold question, for, once a new rule is applied to the defendant in the case announcing the rule, even-lianded justice requires that it be applied retroactively to all who are similarly situated." 24 This statement was rejected by four Justices of the

bar-whether a defendant is entitled to a fair cross-section of the population on the petit jury. By crafting its new retroactivity rules, the Court managed to avoid the issue on procedural grounds. In the next Term, the Court did decide against such a cross section requirement for petit juries. See Holland v. Illinois, $110 \mathrm{~S}$. Ct. 803 (1990).

19. See Teague, 489 U.S. at 300.

20. Until Teague, retroactivity determinations were guided by Linkletter v. Walker, 381 U.S. 618 (1965). In that case, the Court was faced with the question of whether the exclusionary rule of Mapp v. Ohio, 367 U.S. 643 (1961), was to be applied retroactively. The Court determined that retroactivity questions should be answered by exannining the purposes of the rule in question, the reliance of the States on prior law, and the effect on the administration of justice of a retroactive application of such a rule. See Linkletter, 381 U.S. at 636 . Under that standard, the Mapp rule was held to apply only to trials that commenced after that case was decided. Id. at 640 .

In practice, the rules laid out in Linkletter proved difficult to apply:

The Linkletter retroactivity standard has not led to consistent results. Instead, it has been used to limit application of certain new rules to cases on direct review, other new rules only to the defendants in the cases announcing such rules, and still other new rules to cases in which trials have not yet commenced. Not surprisingly, commentators have "had a veritable field day" with the Linkletter standard, with much of the discussion being "more than mildly negative."

Teague, 489 U.S. at 302-03 (quoting Francis X. Beytagh, Ten Years of Non-Retroactivity: A Critigue and a Proposal, 61 VA. L. Rev. 1557, 1558 (1975)).

21. See Brief Amicus Curiae of the Criminal Justice Legal Foundation in Support of Respondent at 4-5, Teague (No. 87-5259).

22. Teague, 489 U.S. at 300 (citation omitted).

23. Id. (quoting Paul J. Mishkin, The Supreme Court, 1964 Term-Foreword: The High Court, The Great Writ, and the Due Process of Time and Law, 79 HARv. L. REv. 56, 64 (1965)).

24. Id. 
Court, ${ }^{25}$ and only grudgingly adopted by a fifth. ${ }^{26}$ Under the plurality's new approach, therefore, if the habeas petitioner advocates the adoption of a new rule, the court must make an initial determination as to the retroactive effects of such a rule before considering the argument on the merits.

The Teague court recoguized the problems inherent in such a deterinination, noting that "[i]t is adinittedly often difficult to determine when a case announces a new rule, and we do not attempt to define the spectrum of what inay or may not constitute a new rule for retroactivity purposes."27 However, the plurality went on to do exactly that:

In general, however, a case announces a new rule when it breaks new ground or imposes a new obligation on the States or the Federal Government. To put it differently, a case announces a new rule if the result was not dictated by precedent existing at the time the defendant's conviction became final. ${ }^{28}$

Thus, the plurahty adopted two different definitions of what constitutes a "new rule," apparently assuming the two to be functionally equivalent. Having dispensed with the definition of a "new rule," the plurality then adopted Justice Harlan's premise that "new rules generally should not be apphed retroactively to cases on collateral review."29

The underlying explanation for Justice Harlan's (and the plurality's) adoption of this doctrine lies in his view of the fundamental purpose of the writ of habeas corpus. Justice Harlan strongly argued that the priinary function of the writ was to deter state court misconduct, ${ }^{30}$ and that

25. See id. at 318-19 (Stevens, J., concurring in part and in judgment) (joined by Justice Blackmun); id. at 339 (Brennan, J., dissenting) (joined by Justice Marshall).

26. See id. at 317 (White, J., concurring in part and in judgment).

27. Id. at 301 .

28. Id. (citations omitted). The extraordinary breadth of this definition and its ability to sweep nearly every Supreme Court decision within its scope are illustrated by later cases. See, e.g., Butler v. McKellar, 110 S. Ct. 1212, 1214 (1990) (rule barring police-initiated interrogation following a suspect's request for counsel in the context of a separate investigation deemed new even though other courts anticipated the decision); Saffle v. Parks, 110 S. Ct. 1257, 1260 (1990) (rule requiring that jurors be allowed to base a capital sentencing decision on sympathy labelled new); Sawyer v. Sinith, 110 S. Ct. 2822, 2828 (1990) (rule of Caldwell v. Mississippi, 472 U.S. 320 (1985), that a prosecutor may not seek to diminish the jury's sense of responsibility in capital sentencing decisions, held to be new).

29. Teague, 489 U.S. at 305; see Mackey v. United States, 401 U.S. 667, 682 (Harlan, J., concurring in part and dissenting in part); Desist v. United States, 394 U.S. 244, 263 (Harlan, J., dissenting).

30. Justice Harlan stated:

[T] he threat of habeas serves as a necessary additional incentive for trial and appellate courts throughout the land to conduct their proceedings in a manner consistent with established constitutional standards. In order to perform this deterrence function, the habeas court need not, as prior cases make clear, necessarily apply all "new" constitutional rules retroactively. In these cases, the habeas court need only apply the constitutional standards that prevailed at the time the original proceedings took place.

Desist, 394 U.S. at 262-63 (Harlan, J., dissenting). 
therefore the federal courts should defer to the states whenever the state court faithfully applied the law existing at the time of the trial. Others, including Justice Brennan in his dissent in Teague, feel just as passionately that the function of habeas corpus is to ensure that the conviction or sentence complies with the dictates of the Constitution, regardless of the good faith of the state courts. ${ }^{31}$ It is this fundamental disagreement over the purpose of habeas corpus that is at the root of the disagreement between the Justices; those Justices who feel that the Great Writ was designed to serve both purposes will likely become the swing votes in future decisions.

The language of Justice Harlan's rule is important to note: "[N]ew rules generally should not be applied retroactively to cases on collateral review."32 The use of "generally" was not without meaning; Justice Harlan recognized two exceptions to his rule, the first being that "a new rule should be applied retroactively if it places 'certain kinds of primary, private individual conduct beyond the power of the criminal law-making authority to proscribe." "33 The Teague plurality adopted this exception without alteration. ${ }^{34}$ The second exception recoguized that "a new rule should be applied retroactively if it requires the observance of 'those procedures that ... are implicit in the concept of ordered liberty." "35 This second exception was applied by the plurality "with a inodification"36 replacing the "implicit in the concept of ordered liberty" formulation witl a narrower "waterslied rules of criminal procedure" construction. ${ }^{37}$

31. See Teague, 489 U.S. at 326 (Brennan, J., dissenting). The legislative history surrounding the federal habeas corpus statute provides no clear answer to this dispute; one commentator, however, has observed that "[a]t the most elementary level, a statute passed in 1867 that expands federal jurisdiction over the state criminal justice system is not hard to read. The agenda of Congress in 1867 was clear, and deference to state criminal courts was not on it." Michael E. Tigar, Habeas Corpus and the Penalty of Death, 90 COLUM. L. REv. 255, 269 (1990) (reviewing JAMES S. LJEBman, Federal Habeas Corpus Practice and Procedure (1988)). For a discussion of the history of and controversy over habeas corpus, see CHEMERJNSKY, supra note 4, $\S$ 15.1-.2.

32. Teague, 489 U.S. at 305 (emphasis added).

33. Id. at 307 (quoting Mackey v. United States, 401 U.S. 667, 692 (1971) (opinion of Harlan, J.)). However, this exception would be met only in the rarest of cases; in fact, the Court itself is hard-pressed to come up with examples. See id. at 334 (Brennan, J., dissenting). But see Penry v. Lynaugh, 492 U.S. 302, 330 (1989) (permitting petitioner's claim that mentally handicapped persons should be exempt from the death penalty to fall within the first exception).

34. See Teague, 489 U.S. at 310 . Although the Court simply stated that the first exception was not applicable in this case, the implication was that it would have been used if it were. Later cases explicitly adopt this first exception. See Penry, 492 U.S. at 329 (1989).

35. Teague, 489 U.S. at 307 (quoting Mackey v. United States, 401 U.S. 667, 693 (1971) (opinion of Harlan, J.)). The Court's paradigm example of such a rule is the Gideon v. Wainwright requirement of appointed counsel for indigent defendants. See Saffle v. Parks, 110 S. Ct. 1257, 1264 (1990).

36. Teague, 489 U.S. at 311 . This "modification" prompted Justice Stevens to write a separate concurring opinion. See id. at 318 (Stevens, J., concurring in part and in judgment).

37. Id. at 311. 
The Teague plurality justified this alteration by asserting that Justice Harlan had not intended to use the words he chose: "The language used by Justice Harlan . . . leaves no doubt that he meant the second exception to be reserved for watershed rules of criminal procedure." 38 Of course, as Justice Stevens pointed out in his concurring opimion, there is indeed substantial doubt as to what Justice Harlan meant; Justice Stevens preferred to assume that the learned Justice meant exactly what he said. ${ }^{39}$

The plurality defended its modification on the grounds that the phrase "implicit in the concept of ordered hiberty" was simply borrowed by Justice Harlan from Palko v. Connecticut, ${ }^{40}$ and should not be applied outside the realm of incorporation doctrine. ${ }^{41}$ Further, the Court noted that since Justice Harlan formulated his test, "our cases have moved in the direction of reaffirming the relevance of the likely accuracy of convictions in determining the available scope of habeas review."42 Thus, the plurality concluded that the second exception applied only "to those new procedures without which the likelihood of an accurate conviction is seriously diminished." 43

The result of the Teague decision was that the framework for review of habeas corpus petitions had been redesigned, but not completely settled. After Teague, the doctrine stood as follows: A presumption of non-retroactivity, and hence against consideration, attached to every "new" claim raised in a petition for habeas corpus. If the claim at issue were not "new," there would be no barrier to a hearing on the merits. Unfortunately, the Teague court provided two very different definitions of "new," each subject to its own interpretation, ${ }^{44}$ and both very broad. If the clain was indeed classified as "new," the presumption against consideration on the merits conld be overcoine only if one of two exceptions were satisfied. The first allowed a consideration on the merits if the desired rule would place the individual conduct in question beyond the enforcement power of the state, that is, if the rule sought wonld declare certain activity legal rather than illegal. The second exception allowed

38. Id.

39. See id. at 320 (Stevens, J., concurring in part and in judgment).

40. 302 U.S. 319 (1937). Palko was the first case to advocate the theory of selective incorporation, whereby the Due Process Clause of the Fourteenth Amendment was deemed to have made only certain portions of the Bill of Rights applicable to the states.

41. See Teague, 489 U.S. at 312 ("Were we to employ the Palko test without more, we would be doing little more than importing into a very different context the terms of the debate over incorporation. . . Reviving the Palko test now, in this area of the law, would be unnecessarily anachronistic.").

42. Id. at 313. In his dissent, Justice Brennan took issue with the cases cited by the plurality in support of this position. See id. at 337 n.6 (Brennan, J., dissenting).

43. Id. at 313.

44. See supra text accompanying note 28 . 
consideration on the merits if the rule sought was a "watershed rule of crimmal procedure" or if it implicated "those new procedures without which the likelihood of an accurate conviction is seriously diminished." Announced im February of 1989, Teague settled the issue for only four months.

\section{Application of Teague in the Capital Context}

Although the Teague opimion stated that it did not "express any views as to how the retroactivity approach we adopt today is to be applied im the capital sentencing context," 45 it went on to do just that:

We do, however, disagree with Justice Stevens' suggestion that the finality concerns underlying Justice Harlan's approach to retroactivity are limited to making convictions final, and are therefore wholly inapplicable to the capital sentencing context. ... Collateral challenges to the sentence in a capital case, like collateral challenges to the sentence in a non-capital case, delay the enforcement of the judgment at issue and decrease the possibihity that "there will at soine point be the certainty that comes with an end to litigation."46

In late June of the 1988 Term, the Court faced its first opportunity to apply the Teague doctrime im a capital case. That case, Penry $v$. Lynaugh, ${ }^{47}$ had been argued before Teague was decided, so, as in Teague, the Court addressed the retroactivity issue without benefit of briefing or discussion by the parties. Once again, Justice O'Connor delivered the opinion of the Court; once again, her opmion was not joined by a majority. In fact, no other Justice joined Justice O'Connor's full opinion. However, four other Justices did join a critical section of the opinion that stated that the Teague doctrime apphed to capital as well as noncapital cases. 48

After disingenuously stating that Teague had expressed no views on retroactivity for capital cases, the Penry Court dispensed with the issue in one sentence: "In our view, the finality concerns underlying Justice Harlan's approach to retroactivity are applicable in the capital sentencing context, as are the two exceptions to his general rule of nonretroactivity." 49 Thus, im that single sentence, a majority of the Supreme Court

45. Teague, 489 U.S. at 314 n.3.

46. Id. (quoting Sanders v. United States, 373 U.S. 1, 25 (1963) (Harlan, J., dissenting)) (other quotations omitted). Although the Teague plurality may have supported this proposition, if they are insinuating that Justice Harlan did as well, that contention is not supported by Sanders. Sanders was not a capital case (the petitioner there was challenging his 15-year sentence for bank robbery), and so it is misleading for the Teague Court to append Justice Harlan's phrase to an assertion that capital and non-capital cases should be treated equivalently.

47. 492 U.S. 302 (1989). For a fuller discussion of Penry, see supra sources cited in note 17.

48. See Penry, 492 U.S. at 314; id. at 351 (Scalia, J., concurring in part and dissenting in part).

49. Id. at 314 (citation omitted). 
decided that procedural retroactivity issues were paramount to the assurance of a constitutionally valid sentence that would result in the infliction of the ultimate pumishment.

The end result of Penry behies the invidiousness of its rule. The Court held that a rule sought by Penry relating to jury instructions regarding mitigating evidence was "dictated" by prior precedent (and thus was not a "new rule"),, and that a separate claim brought by Penry fell within the first Teague exception, and as such could be considered on the merits. ${ }^{51}$ Thus, the case was remanded for further consideration. In fact, as supporters of Justice O'Connor's opimon would point out, the Court expressly modified the language of the first Teague exception to accommodate Penry's claim. ${ }^{52}$ That modification is shight, however, and will not appreciably affect the operation of the rule for the majority of criminal defendants.

Penry generated vigorous dissents from both "wings" of the bench. Justice Brennan, joined by Justice Marshall, argued that the Eighth Amendment barred the execution of the mentally retarded, ${ }^{53}$ and took the majority to task for their extension of the Teague doctrine to capital cases:

This extension means that a person may be killed although he or she has a sound constitutional claim that would have barred his or her execution had this Court only announced the constitutional rule before his or her conviction and sentence became final. It is intolerable that the difference between hife and death should turn on such a fortuity of timing, and beyond my comprehension that a majority of this Court will so bhthely allow a State to take a human hife though the method by which sentence was determined violates our Constitution. ${ }^{54}$

Justice Stevens, joined by Justice Blackmun, stated in a brief opinion that he did "not support the Court's assertion, without benefit of argument or briefing on the issue, that Teague's retroactivity principles pertain to capital cases." ss

Justice Scalia also dissented, but from a different portion of the opinion than did Justice Breıman. Justice Scalia viewed Justice O'Connor's

50. See id. at 319 .

51. See id. at 330 .

52. Specifically, the Court stated: "[T] $]$ he first exception set forth in Teague should be understood to cover not only rules forbidding criminal punishment of certain primary conduct but also rules prohibiting a certain category of punishment for a class of defendants because of their status or offense." Id. Penry, who was mentally retarded, claimed that the execution of mentally retarded defendants violated the Eighth Amendment regardless of the procedures followed. The Court rejected this contention on the merits, stating that no national consensus against the execution of the mentally retarded had yet developed. See id. at 335.

53. See id. at 349 (Brennan, J., concurring in part and dissenting in part).

54. Id.

55. Id. (Stevens, J., concurring in part and dissenting in part). 
slightly permissive interpretation of the "new rule" definition as an illadvised retreat from the dictates of Teague: "It is rare that a principle of law as significant as that in Teague is adopted and gutted in the same Term."56 Justice Scaha's opinion was joined by Chief Justice Rehnquist and Justices White and Kennedy, thus leaving the "conservatives" just one vote shy of a majority.

Justice O'Connor's opinion did little to clarify the definitional ambignities within the Teague doctrine. Early in the opimion, Justice O'Connor seemed to adopt yet a third formulation of the "new rule" definition, this one taken from one of Justice Harlan's decisions. ${ }^{57}$ However, in the holding of the opinion, Justice O'Connor stated that the rule sought by Penry was "not a 'new rule' under Teague because it is dictated by [prior precedent]," 58 thereby adopting the arguably more restrictive "dictated by prior precedent" definition of what constitutes a new rule. As to the two exceptions, the definition of the first was expanded by the Court, 59 whereas the second was not inplicated in the case and therefore not referenced.

Of more than passing interest is the suggestion by Justice Scalia that “a 'new rule, for purposes of Teague, must include not only a new rule that replaces an old one, but a new rule that replaces palpable uncertainty as to what the rule might be."60 Justice Scalia, then, proposed that the word "dictated" be taken hiterally, and that if any doubt existed as to the result of the petitioner's claim, it would be denominated as "new."

\section{The 1989 TeRm: Clarification AND Limitation}

\section{A. Butler v. McKellar}

At the end of the 1988 Tern, Penry remained the Court's last word on retroactivity in habeas corpus proceedings. However, the fact that four Justices would have broadened the definition of "new" while limiting the scope of the exceptions, and that four other Justices were upset at the application of Teague to capital cases without benefit of briefing or

56. Id. at 353 (Scalia, J., concurring in part and dissenting in part).

57. See id. at 314 (quoting Mackey v. United States, 401 U.S. 667, 695 (1971) (separate opinion of Harlan, J.)):

Justice Harlan recognized "the inevitable difficulties that will arise in attempting to determine whether a particular decision has really announced a 'new' rule at all or whether it has simply applied a well-established constitutional principle to govern a case which is closely analogous to those which have been previously considered in the prior case law."

58. Id. at 319 .

59. See id. at 341 ; supra note 52 and accompanying text.

60. Penry, 492 U.S. at 352 (Scalia, J., concurring in part and dissenting in part). This position is noteworthy because it is ultimately adopted by a majority of the Court, but in an even broader form: The new definition essentially removes the qualifier "palpable," allowing any uncertainty to suffice. See Butler v. McKellar, 110 S. Ct. 1212, 1217 (1990). 
argument, signaled that clarification was needed. The opportunity presented itself shortly into the 1989 Term; in Butler $v$. McKellar, ${ }^{61}$ the Court defined what constituted a "new rule" more clearly, if not more fairly.

In Butler, the petitioner was arrested by police on an assault and battery charge. After invoking his right to counsel, he was represented by a court-appointed lawyer at a bond hearing on the charge. Butler was later informed, while still in custody, that he was a suspect in an unrelated murder. He was read his Miranda rights, stated that he understood them, and signed two "waiver of rights" forms. Butler was then interrogated by police concerning the murder, at which time he gave two conflicting accounts of his involvement in the case. These statements were admitted, over objection, at Butler's trial, and he was subsequently convicted and sentenced to death. ${ }^{62}$ His conviction became final when the Supreme Court denied certiorari on direct appeal in 1982.63

After unsuccessfully pursuing state post-conviction remedies, Butler filed a petition for habeas corpus in 1986. That petition was dismissed on the State's motion for summary judgment, and Butler appealed. ${ }^{64}$ On appeal, Butler claimed that the Supreme Court's decision in Edwards v. Arizona, ${ }^{65}$ which forbids the police from questioning a suspect about a particular offense once the suspect has exercised his right to counsel for that offense, ${ }^{66}$ required the police to refrain from any questioning once a defendant invokes his right to counsel on any offense. In support of this contention, Butler rehed upon a Seventh Circuit case that had reached basically the same conclusion. ${ }^{67}$ Unfortunately for Butler, his case was being heard by the Fourth Circuit, which rejected the Seventh Circuit's decision as unpersuasive. ${ }^{68}$ On the same day that the Fourth Circuit denied Butler's petition for rehearing, the Supreme Court decided Arizona v. Roberson, ${ }^{69}$ which adopted Butler's contentions concerning the pernissible scope of interrogation after a request for counsel has been made. ${ }^{70}$ Naturally, Butler moved for a reconsideration, which the Fourth Circuit dened (over a dissent), stating that the limitations on
61. 110 S. Ct. 1212 (1990).
62. Id. at 1215 .
63. Butler v. South Carolina, 459 U.S. 932 (1982).
64. Butler, $110 \mathrm{~S}$. Ct. at 1215.
65. 451 U.S. 477 (1981).
66. See id. at 484-85.
67. United States ex rel. Espinoza v. Fairman, 813 F.2d 117, 126-27 (7th Cir.), cert. denied, 483 U.S. 1010 (1987).

68. See Butler v. Aiken, 846 F.2d 255, 258 (4th Cir. 1988).

69. 486 U.S. 675 (1988).

70. See id. at 677-78. 
police interrogation were only tangentially related to the truth-finding function. ${ }^{71}$ Butler then appealed to the Supreme Court.

The primary question presented in Butler was whether Roberson represented a new rule, or whether its result was dictated by the Court's 1981 holding in Edwards. If the former, Butler would not be heard on the merits unless he could satisfy one of the two Teague exceptions; ${ }^{72}$ if the latter, his petition would be considered in full ${ }^{73}$ (and, on the facts as presented, almost certainly granted). The petitioner argued that the factual distinctions between Roberson and Edwards were de minimis, and msufficient to implicate any state rehance issue. ${ }^{74}$ Indeed, in Roberson, the Court had adopted the Arizona Supreme Court's reasoning that "[t]he only difference between Edwards and the appellant is that Edwards was questioned about the same offense after a request for counsel while the appellant was reinterrogated about an unrelated offense. We do not beheve that this factual distinction holds any legal significance for fifth ainendment purposes."75 Nevertheless, the Supreme Court found this factual distimction sufficient to create a new rule, and affirmed Butler's conviction without reaching the merits. ${ }^{76}$

Initially, Chief Justice Rehnquist noted the inportant difference between the two formulations of the "new rule" definition:

[I]n general, a case announces a "new rule" when it breaks new ground or imposes a new obligation on the States or the Federal Government. Put differently, and, indeed, more meaningfully for the majority of cases, a decision announces a new rule "if the result was not dictated by precedent existing at the time the defendant's conviction became final.""77

After quoting extensively from Teague, he then concluded that " $[t]$ he 'new rule' principle therefore validates reasonable, good-faith interpretations of existing precedents made by state courts even though they are shown to be contrary to later decisions."78 In support of this

71. See Butler v. Aiken, 864 F.2d 24, 25 (4th Cir. 1988). The Fourth Circuit's decision was made before Teague, and matters such as the relation to the truth-finding function were still proper subjects for discussion under the Linkletter standards. See supra note 20.

72. See supra text accompanying notes 32-39.

73. See supra text accompanying note 44 .

74. Brief for Petitioner at 9-10, Butler v. McKellar, 110 S. Ct. 1212 (1990) (No. 88-6677).

75. Roberson, 486 U.S. at $677-78$ (quoting State v. Routhier, 669 P.2d 68, 75 (Ariz. 1983), cert. denied, 464 U.S. 1073 (1984)).

76. The dccision was 5-4, with Justices White, O'Connor, Scalia, and Kennedy joining Chief Justice Rehnquist's majority opinion. Justice Brennan dissented, joined by Justices Marshall, Blackmun, and Stevens (Justices Blackmun and Stevens joined all but section IV of Justice Brennan's opinion, which reiterated his categorical opposition to the death penalty). See Butler, $110 \mathrm{~S}$. Ct. at 1214.

77. Id. at 1216 (quoting Penry v. Lynaugh, 492 U.S. 302, 314 (1989)).

78. Id. at 1217. 
position, the Chief Justice provided a $c f$. cite to United States $v$. Leon, ${ }^{79}$ which involved a good-faith exception to the exclusionary rule. In an attached parenthetical, the Butler Court explained the deterrence function of the exclusionary rule, and how it would not be served by keeping out evidence obtained by "objectively reasonable law enforcement activity."80

The only plausible explanation for the Chief Justice's conclusion is that at least five Justices of the Court now beheve that the primary purpose of the writ of habeas corpus is to deter state court misconduct, and that therefore state courts should not be held accountable via habeas corpus in any manner that would not further that end. If this premise is accepted, Chief Justice Rehnquist's reasoning is easier to understand, because a "good-faith" inquiry into the state court's decision would serve the desired deterrence function. The Court went on to say that even if a court exphicitly states that its decision is "controlled" by a prior decision, such an assertion is not dispositive for "new rule" determinations. ${ }^{81}$ As long as "the outcome in Roberson was susceptible to debate among reasonable minds," 82 that outcome constituted a "new rule."

Not surprisingly, this restructuring of the "new rule" definition to include virtually every case worthy of the Court's attention provoked a lengthy and vehement dissent. For adherents to the view that the Great Writ exists not to police the states but to renedy injustice, these developments were a crushing blow. Justice Bremian, joined by Justices Marshall, Blackmun, and Stevens, ${ }^{83}$ attacked the majority's new formulation on the grounds that every case decided by the Court would announce a new rule unless a contrary outcome "could not be defended by any reasonable jurist." 84

The dissenters noted that, under this expansive "new rule" defimtion, the federal courts are only allowed to inquire into whether the state court's legal analysis can be justified in any reasonable manner

79. 468 U.S. 897 (1984). Leon concerned whether the prophylactic requirements of the exclusionary rule should apply where the police officers hold a good faith belief as to the probable cause supporting the warrant. The Court, after a thorough discussion of the purposes of the exclusionary rule, decided that it should not. See id. at 918-19.

80. Butler, $110 \mathrm{~S}$. Ct. at 1217 . The Chief Justice's reasoning is surprising considering that no comparison between the exclusionary rule and the Great Writ had ever been so much as suggested. Except for sharing a common word in their purpose (deterrence), the exclusionary rule and the writ of habeas corpus are totally unrelated. The former is an evidentiary rule, designed wholly by the courts to remedy violations of the Fourth Amendment, whereas the latter is a constitutional guarantee, implemented by congressional enactment to prevent the unconstitutional detention of citizens.

81. See id.

82. Id.

83. See id. at 1218 (Brennan, J., dissenting).

84. Id. at 1219. 
whatsoever. ${ }^{85}$ This is equivalent to review under a "clearly erroneous" standard, which would prevent the district courts from conducting their own analyses of the prevailing law at the time the petitioner's conviction became final. Instead, they "must defer to the state court's decision rejecting the claim unless that decision is patently unreasonable." 86

The majority's expansion of the "new rule" definition thus eliminates the very rationale they designed it to support. That rationale was intended to deter state court deviations from federal constitutional law. Indeed, the majority rejected the rationale that "fairness" rather than "deterrence" is the goal. ${ }^{87}$ Yet the deterrence function embraced by the majority is actually weakened by the broadened definition. State courts need not decide federal constitutional claims "correctly," as advocated by the Teague plurality; ${ }^{88}$ rather, they must only evaluate such claims "reasonably." 89 Thus, state courts have hittle incentive to interpret conscientiously federal constitutional law; they may decide such cases without consideration of marginally distinguishable precedent. State courts may thus rest easy, secure in the knowledge that their reasoning will not be challenged by a habeas corpus petition, provided that their ultimate position does not prove indefensible under existing law.

Because the primary issue of the case related to the definition of "new," the Butler inajority made very hittle mention of the two exceptions that are implicated if the claim is indeed deemed "new." The inajority did exphicitly recoguize the Penry expansion of the first exception, ${ }^{91}$ and quoted extensively from Teague with respect to the second.92 As to the second exception, the Court determined that a violation of the Roberson restrictions "would not seriously diminish the likelihood of obtaining an accurate determination." 93 No mention is made of the more restrictive "watershed rules of criminal procedure" version of the second exception, and so one might think that the accepted definition for the second exception had been settled, along with the rest of the doctrine. This was not the case.

\footnotetext{
85. See id.

86. Id. at 1221.

87. See id. at 1217.

88. See Teague v. Lane, 489 U.S. 288, 306-07 (1989).

89. See Butler, $110 \mathrm{~S}$. Ct. at 1223 (Brennan, J., dissenting).

90. See id. at 1218.

91. See id.

92. See id.

93. Id.
} 
B. Saffle v. Parks

On the same day that Butler was decided, the Court announced its decision in Saffle v. Parks. ${ }^{94}$ Parks was convicted of the murder of a gas station attendant, and prosecutors for the state of Oklahoma sought the death penalty. At the sentencing phase of the trial, the judge instructed the jury to avoid any influence of sympathy when determining Parks's sentence. After finding a statutory aggravating circumstance, the jury sentenced Parks to death. ${ }^{95}$ Parks's conviction became flnal in 1983 when the Supreme Court denied his petition for certiorari.96 Parks then filed a inotion for a writ of habeas corpus, claiming that the anti-sympathy instruction violated the Eighth Amendment, in that it effectively told the jury to disregard the initigating evidence Parks had presented. Parks lost in the District Court and in a divided panel of the Tenth Circuit on appeal, ${ }^{97}$ but prevailed upon rehearing en banc. ${ }^{98}$

Writing for the Court, Justice Kennedy crafted his own version of the "new rule" definition, stating that a rule would be considered new unless a state court "would have felt coinpelled by existing precedent to conclude that the rule ... [sought] was required by the Constitution."99 The inpotence of this definition to provide any petitioner with rehef is illustrated by the Court's analysis of Parks's legal argument.

Parks based his Eighth Amendinent arguinent on two cases, Lockett v. Ohio ${ }^{100}$ and Eddings v. Oklahoma, ${ }^{101}$ both of which were decided before Parks's conviction became final. These cases stated that the sentencing body (judge or jury) could not refuse as a inatter of law to consider any initigating evidence offered by the defendant, regardless of whether such initigating factors were delineated as such by statute. The judge's instruction, argued Parks, directly contravened this principle by forbidding the jury to allow sympathy to affect their determination. ${ }^{102}$

94. 110 S. Ct. 1257 (1990). As might be expected, the court split 5-4, see id. at 1258 , in precisely the same manner as it had in Butler. See Butler, $110 \mathrm{~S}$. Ct. at 1214.

95. Parks, $110 \mathrm{~S}$. Ct. at 1259.

96. Parks v. Oklahoma, 459 U.S. 1155 (1983).

97. Parks v. Brown, 840 F.2d 1496 (10th Cir. 1988).

98. Parks v. Brown, 860 F.2d 1545 (10th Cir. 1988) (en banc).

99. Parks, $110 \mathrm{~S}$. Ct. at 1260.

100. 438 U.S. 586 (1978).

101. 455 U.S. 104 (1982).

102. Parks's contentions had already been considered by the Supreme Court in California v. Brown, 479 U.S. 538 (1987). There, the Court upheld an anti-sympathy instruction, but on the basis that the word "sympathy" was only one of many factors the judge had instructed the jury to avoid, and thus did not impermissibly limit the jury's consideration of mitigating factors. By negative implication, however, if the judge specifically instructed the jury to avoid any influence of sympathy, as he did in Parks, the Brown holding would not protect such an instruction. However, because Brown came after Parks's conviction became final, he could not benefit from it unless it came within one of the two exceptions to the rule against retroactive application. Parks's counsel made no at- 
Justice Kennedy determined that the rule sought by Parks concerned not what evidence could be considered, as did Lockett and Eddings, but how that evidence must be considered, to which Lockett and Eddings did not "speak directly."103 Thus, since that distinction existed, Parks was requestimg a new rule. The Court made very clear just how enormous a barrier it had erected with its "new rule" formulation: "Even were we to agree with Parks' assertion that our decisions in Lockett and Eddings inform, or even control or govern, the analysis of his claim, it does not follow that they coinpel the rule that Parks seeks."104

As a matter of deductive reasoning, it is impossible to draw a distinction between cases that control or govern a case and those that coinpel a particular result. If a case is deemed controlling, it dictates the result, absent a judicial departure from stare decisis. The distinction is merely semantic mumbo-jumbo, and illustrates the lengths to which the majority was willing to go to denominate Parks's claim as "new."

Having thus determmed that Parks sought the benefit of a new rule, the Court addressed the exceptions to the general prohibition against deciding such cases. The first was clearly inapplicable to Parks, as his requested rule would neither decriminalize inurder nor prohibit the inposition of the death penalty on a particular class of persons. ${ }^{105}$ As to the second, Justice Kennedy adopted the "watershed rules of criminal procedure" version and held that Parks's claim did not come within its bounds. ${ }^{106}$ In so doing, Justice Kennedy ignored the "diminish the likelihood of an accurate determination" formulation adopted by Chief Justice Rehnquist earlier in the day. It appeared that the Court had decided that the two formulations were functionally equivalent, and thus could be used intercliangeably. Neither opimion discussed any potential difference between the definitions, and so botl remained in force-for the time being.

\section{Sawyer v. Smith}

Any doubts surrounding the scope of the second exception were resolved by Sawyer $v$. Smith, ${ }^{107}$ the Court's final retroactivity decision of the 1989 Term. In Septeinber of 1980, Sawyer was found guilty of firstdegree murder in the gruesoine death of a rooniniate of Sawyer's girl-

\footnotetext{
tempt, however, to fit within either one; in fact, retroactivity was not discussed in the briefs at all by either party, nor by the State of California as amicus, although it was discussed at oral argument.

103. Parks, 110 S. Ct. at 1261 .

104. Id.

105. See id. at 1263.

106. See id. at $1263-64$.

107. 110 S. Ct. 2822 (1990). As in both Butler and Parks, the Court split 5-4, with the same Justices on each side. See id. at 2824.
} 
friend. During the sentencing phase of the trial, the prosecution repeatedly told the jury that its sentencing decision would be reviewed by a higher court, and that any error would thereby be corrected. The jury subsequently sentenced Sawyer to death. ${ }^{108}$ Sawyer's conviction becaine final in 1984 when, after a previous remand, the Supreme Court demed certiorari. ${ }^{109}$ One year later, in Caldwell v. Mississippi, ${ }^{110}$ the Supreme Court held that any jury argument by the prosecution that diminishes the jury's sense of responsibility in a capital case violates the Eighth Ainendinent. ${ }^{111}$ Sawyer's petition for habeas corpus was filed shortly thereafter.

Unlike Butler and Parks, Sawyer had no reasonable argument that the decision in Caldwell, upon which he rehed, was not a new rule; a previous Supreme Court case had rejected the suggestion that the Caldwell rule was required by the Eighth Amendment, ${ }^{112}$ so Caldwell's holding was a complete reversal of earher precedent. Because Caldwell was decided after Sawyer's conviction became final, he could only prevail if he could qualify for retroactive application under one of the two exceptions. ${ }^{113}$ As in the cases earlier in the Terin, the first was unavailing, ${ }^{114}$ in that the Caldwell rule did not legalize murder, nor did it prevent the inposition of the death penalty on a particular class of persons. The second exception thus becaine the battleground.

Sawyer was not without ammumition for his assault. One of the reasons the Court granted certiorari was to resolve a conflict within the circuits regarding the scope of the second exception, ${ }^{115}$ and so Sawyer had the decision of at least one federal circuit (the Tenth) on his side. Further, as noted earher, the second exception had been defined in at least two different ways im the past, ${ }^{116}$ and had not been fully imterpreted to this point-giving Sawyer the opportunity to argue for a favorable construction. Also, the equities of the situation favored Sawyer; it could not be gainsaid that the Caldwell rule had been violated in his case, which

108. Id. at 2825 .

109. Sawyer v. Louisiana, 466 U.S. 931 (1984).

110. 472 U.S. 320 (1985).

111. See id. at 328-29.

112. See California v. Ramos, 463 U.S. 992, 1013 (1983).

113. Justice Kennedy initially dealt with the "new rule" question; however, given the dictates of Butler and Parks, this was clearly a perfunctory exercise. Indeed, even under a narrow definition of the term, the Caldwell rule was undoubtedly "new."

114. See Sawyer, $110 \mathrm{~S}$. Ct. at 2831.

115. See Hopkinson v. Shillinger, 888 F.2d 1286, 1292 (10th Cir. 1989) (en banc) (holding that the Caldwell rule fell within the second exception); Sawyer v. Butler, 881 F.2d 1273, 1294 (5th Cir. 1989) (en banc) (holding that the Caldwell rule did not fall within the second exception).

116. See supra text accompanying note 106. 
violation would have certainly constituted reversible error had the case been presented on direct appeal.

In the opinion for the Court, Justice Kennedy adopted the "watershed rules of criminal procedure" construction of the second exception, as he had done in Parks. The full language of Justice Kennedy's definition is important to note: "The second Teague exception applies to new 'watershed rules of criminal procedure' that are necessary to the fundamental fairness of the criminal proceeding." 117 Thus, the Kennedy version of the second exception has two requirements: the rule must be "watershed," and it must implicate the fundamental fairness of the proceeding.

It was this duahty that proved fatal to Sawyer's petition. The Court refused to read the second exception to include new rules of capital sentencing that only "preserve the accuracy and fairness of capital sentencing judgments." 118 According to the majority, such a reading would return the second exception to the broad definition originally supported by Justice Harlan, which they were unwilling to do:

It is thus not enough under Teague to say that a new rule is aimed at improving the accuracy of trial. More is required. A rule that qualifies under this exception must not only improve accuracy, but also alter our understanding of the bedrock procedural elements essential to the fairness of a proceeding. ${ }^{19}$

Justice Kennedy further stated that because the Caldwell rule merely provided an mcremental safeguard to due process protections already in place, ${ }^{120}$ it did not qualify as a bedrock procedural element, and therefore that Sawyer's petition was not entitled to a hearing on the merits. ${ }^{121}$

\section{Status of the Doctrine}

At the close of the 1989 Term, the Supreme Court's retroactivity doctrine for habeas corpus proceedings stood as follows: If the habeas petitioner is claiming the benefit of a "new rule," then that rule's result will not be apphied retroactively, and the court will not hear the claim on the inerits, unless one of two exceptions are met. Three important definitions need to be noted: (1) the defimition of a "new rule"; (2) the formu-

117. Sawyer, 110 S. Ct. at 2831 (quoting Saffle v. Parks, 110 S. Ct. 1257, 1263 (1990)).

118. Id.

119. Id. (quotation omitted).

120. The Court noted that Donnelly v. DeChristoforo, 416 U.S. 637 (1974), already provided relief for defendants when they could demonstrate that the prosecutor's remarks had made the proceeding fundamentally unfair. Thus, according to the majority, defendants need only resort to Caldwell when Donnelly proves unavailing. See Sawyer, 110 S. Ct. at 2832.

121. Sawyer, 110 S. Ct. at 2832. 
lation of the first exception to the presuinption against hearing "new rule" cases; and (3) the second exception to that presumption.

"New rules" are defined as "those that were not dictated by precedent existing at the time the defendant's conviction became final." 122 Put another way, a rule is "new" unless a state court considering the rule at the time the petitioner's conviction became final would have felt compelled by existing precedent to decide that the rule sought was required by the Constitution. ${ }^{123}$ Such compulsion could only coine from a definitive interpretation by the Supreme Court on the issue; decisions from lower federal courts or other state courts would be insufficient. Therefore, if a habeas petitioner seeks to rely on a Supreme Court case, the question of "newness" has ipso facto been resolved against him: The Supreine Court would not have bothered to grant certiorari in the earher case had the issue already been definitively resolved; thus, whatever case is being relied on must be "new." The end result is that, for all intents and purposes, every rule from a Supreme Court case is "new."

Since its modification in Penry, the language of the first exception has reinained the same: A new rule will nevertheless be apphed retroactively if it either places "an entire category of primary conduct beyond the reach of the criminal law"124 or if it prohibits "imposition of a certam type of pumishment for a class of defendants because of their status or offense."125 The opporturities for application of this exception will be few and far between (Penry notwithstanding), so its importance should not be overstated.

Two forinulations of the second exception were used by the Court during the 1989 Term, although the second seeins to have been adopted as controlling. In Butler, Chief Justice Rehnquist defined the exception to include ouly those new procedures without which the likelihood of an accurate conviction is seriously diminished. ${ }^{126}$ However, in Parks, and again in Sawyer, Justice Kelmedy was careful to include withm the second exception only those watershed rules of criminal procedure that are necessary to the fundamental fairness of the criminal proceeding. ${ }^{127}$ Under the Rehnquist formulation, a rule that substantially improves accuracy will be included, whereas under the Kennedy version, only those rules required for the fairness of the proceeding may qualify, and then only if they are considered to be "bedrock" rules of criminal procedure.

122. Id. at 2827 (quotation omitted).

123. See Saffle v. Parks, 110 S. Ct. 1257,1260 (1990).

124. Sawyer, $110 \mathrm{~S}$. Ct. at 2831.

125. Id.

126. See Butler v. McKellar, 110 S. Ct. 1212, 1218 (1990).

127. See Sawyer, 110 S. Ct. at 2831; Parks, 110 S. Ct. at 1263. 
Clearly, the second of these would be the most difficult to meet, as the petitioner must overcome two substantial barriers, rather than a single (arguably lower) one.

\section{The Case for Disparate Treatment of Capital PUNISHMENT}

This Note argues that the Supreme Court failed to adequately consider the unique nature of capital pumishment when it apphed its retroactivity doctrine to capital sentencing cases. ${ }^{128}$ The Court iguored over fifteen years of its own jurisprudence that consistently labeled capital punishment as qualitatively different from non-capital punishment, thus entitling it to individualized application of otherwise general procedural rules.

As a matter of common sense, a death sentence is fundanientally different from even a sentence of life imprisoninent without possibility of parole. The importance of the difference, however, goes much deeper: Through its interpretation of the Eighth Amendinent prohibition against cruel and unusual punishment, the Supreme Court has recoguized that the distinction between capital and non-capital sentencing is of constitutional significance. Since the Court's decision in Furman v. Georgia, 129 the Justices have struggled to define the permissible scope of state capital sentencing statutes and procedures. In the process, the Court has delineated everything from jury instructions ${ }^{130}$ to prosecutorial arguinents, ${ }^{131}$ from statutory aggravating circumstances ${ }^{132}$ to mitigating factors ${ }^{133}$-all to keep the death sentence from violating the dictates of the Constitution. A defendant sentenced to life imprisonment has no cause to claim on appeal that, for example, the jury was not allowed to consider his status as a drug addict, solid citizen, wife-beater, or community volunteer when it passed judgment. Yet one under sentence of death may claim just such an error. Although many Justices of the current Court inay disagree with the path taken by prior Justices in fashioning this body of law, there is general agreement on the Court that unique safeguards are required in capital proceedings. Indeed, even one of the most "conservative" Justices recognizes the continuing validity of Furman, which denands that

128. The author claims no credit for this objection; see Parks, $110 \mathrm{~S}$. Ct. at 1269-70 (Brennan, J., dissenting).

129. 408 U.S. 238 (1972).

130. See Boyde v. California, 110 S. Ct. 1190 (1990); Mills v. Maryland, 486 U.S. 367 (1988);

Hitchcock v. Dugger, 481 U.S. 393 (1987).

131. See Caldwell v. Mississippi, 472 U.S. 320 (1985).

132. See Lewis v. Jeffers, 110 S. Ct. 3092 (1990); Baldwin v. Alabama, 472 U.S. 372 (1985); Zant v. Stephens, 462 U.S. 862 (1983).

133. See Lockett v. Ohio, 438 U.S. 586 (1978); Jurek v. Texas, 428 U.S. 262 (1976). 
courts not have unbridled discretion in imposing the death penalty, yet imposes no such restriction on the imposition of sentences of incarceration. ${ }^{134}$

In its most recent Term, the Court reaffirmed the proposition that the death penalty fundamentally differs froin a term of incarceration. In Harmelin v. Michigan, ${ }^{135}$ the petitioner appealed a sentence of life in prison without possibility of parole imposed for possession of more than 600 grams of cocame. Although the primary basis for petitioner's appeal was the alleged disproportionality of the sentence, ${ }^{136}$ Harmelin also clained that the judge should have been required to consider various mitigating factors when inposing sentence. ${ }^{137}$ In a section of the opinion joined by five "conservative" Justices, ${ }^{138}$ the Court stated that "[o]ur cases creating and clarifying the individualized capital sentencing doctrine' have repeatedly suggested that there is no comparable requirement outside the capital context, because of the qualitative difference between death and all other penalties."139 The Court continued:

In some cases, moreover, there will be neghigible difference between life without parole and other sentences of imprisonment-for example, a life sentence with eligibility for parole after 20 years, or even a lengthy term sentence witlout eligibility for parole, given to a 65 -year-old man. But even where the difference is the greatest, it cannot be compared with deatl. We lrave drawn the hine of required individualized sentencing at capital cases, and see no basis for extending it further. ${ }^{140}$

Thus, the recognition that capital punishment is quahtatively different from all other forms of punishment is deeply entrenched within the Supreine Court's interpretation of the Eighth Amendnient. Indeed, Jus-

134. See Walton v. Arizona, 110 S. Ct. 3047,3059 (Scalia, J., concurring in part and iu judgment). Justice Scalia's opinion may set the stage for future battles between the "conservative" and "liberal" elements over the death penalty, because Justice Scalia expressiy disavowed continued adherence to the Court's requireinent that a defendant may present any initigating evidence whatsoever, and that any action on the part of the court to restrict such presentation constitutes reversible error. According to Justice Scalia, Furman expressly requires more control over capital sentencing proceedings, not less, and should not be solely restricted to control over aggravating circumstances. See id. at 3064 . Thus, attempts by states to dictate which mitigating factors are admissible should not only be encouraged, but required. Justice Stevens wrote separately in the case just to address and refute Justice Scalia's position. See id. at 3086 (Stevens, J., dissenting).

135. 111 S. Ct. 2680 (1991).

136. See id. at 2684 (opinion of Scalia, J.).

137. See id. at 2701.

138. Justice Scalia was joined in this section by Chief Justice Rehnquist and Justices O'Connor, Kennedy, and Souter.

139. Harmelin, 111 S. Ct. at 2702 (emphasis added).

140. Id. 
tice Blackmun has stated that the concept "is as firmly established as any in our Eighth Amendment jurisprudence." 141

Unfortunately, with the notable exception of Harmelin, in recent years the Court has not always paid heed to Justice Blackmun's admonishment, although the dissenters have not been shy in instructing the majority as to the error of its ways. In 1990, the Court upheld Arizona's capital sentencing procedures as consistent with the Sixth, Eighth, and Fourteenth Amendments. ${ }^{142}$ Among the aspects of the Arizona law was the requirement that the defendant hold the burden of proof as to any mitigating evidence he might submit. In affirming this requirement, the Court rehed, at least in part, upon prior non-capital cases in which placement of the burden of proof on the defendant for a particular issue had been upheld. In dissent, Justice Blackmun ${ }^{143}$ took the majority to task:

[I]t makes no sense to analyze petitioner's claim . . . by drawing on "analogous" cases outside the sphere of capital sentencing. In developing the requirennent of individualized capital sentencing (with unlimited presentation of relevant mitigating evidence), this Court has not purported to rely on principles applicable to criminal prosecutions generally. Instead, the Court's Eighth Amendment jurisprudence exphicitly has proceeded from the premise "that death is a punishment different from all other sanctions in kind rather than degree."144

It is against this backdrop that the error of the current retroactivity doctrine begins to take shape.

\section{A Modified Approach in Capital CASES}

In the author's opinion the death penalty does not constitute cruel and unusual punshment per se. It is, however, the author's view that

141. Barefoot v. Estelle, 463 U.S. 880, 924 (1983) (Blackmun, J., dissenting). There have been numerous cases reiterating the same principle. Some have been majority opinions, see California v. Ramos, 463 U.S. 992, 998-99 (1983); Solem v. Helm, 463 U.S. 277, 289 (1983); Zant v. Stephens, 462 U.S. 862, 884-85 (1983); Beck v. Alabama, 447 U.S. 625, $637-38$ (1980); Rummel v. Estelle, 445 U.S. 263, 272 (1980); Loekett v. Ohio, 438 U.S. 586, 604 (1978), others pluralities, see Gardner v. Florida, 430 U.S. 349, 357-58 (1977) (plurality opinion); Gregg v. Georgia, 428 U.S. 153, 188 (1976) (plurality opmion), still others dissents, see Whitmore v. Arkansas, 110 S. Ct. 1717, 1729-30 (1990) (Marshall, J., dissenting); Boyde v. California, 110 S. Ct. 1190, 1202 (1990) (Marshall, J., dissenting); Spaziano v. Florida, 468 U.S. 447, 468 (1984) (Stevens, J., concurring in part and dissenting in part); Strickland v. Washington, 466 U.S. 668, 704-05 (1984) (Brennan, J., concurring in part and dissenting in part); id. at 715 (Marshall, J., dissenting); Solem v. Helm, 463 U.S. 277, 306 (1983) (Burger, C.J., dissenting).

142. See Waltou v. Arizona, 110 S. Ct. 3047 (1990).

143. Justice Blackmun was joined by Justices Brennan, Marshall, and Stevens, a coalition that repeatedly appears in dissent from many of the current Court's death penalty rulings. Of course, with the replacement of Justice Brennan with Justice Souter, and the replacement of Justice Marshall with Justice Thomas, that alliance faces an even steeper challenge to command a majority in the future.

144. Walton, 110 S. Ct. at 3072 (Blackmun, J., dissenting) (quoting Woodson v. North Carolina, 428 U.S. 280, 303-04 (1976) (plurality opinion)). 
such a sentence should be imposed only when the state has comphed with every procedural requirement of the Constitution, and only then when the defendant has been given an opportunity for a meaningful federal appeal. Further, it offends all core notions of civilization and decency to execute a person under a prejudical sentence of death, simply because the powers that be did not determine the existence of its prejudicial nature until after the defendant had crossed the Rubicon (i.e., until after his conviction had become final). ${ }^{145}$ As commentator Michael Tigar has pointed out: "[A] death sentence [sh]ould only be carried out if the standards of justice that led to it were fair as measured at the time of the proposed execution, and not at the time of the crime or at some point during the review process." 146

Thus, the existing doctrine in this area requires modification. One could persuasively argue that the entire formulation should be thrown out and a new theory be constructed from the ground up. As appealing as that may sound to some, it has little practical usefulness, for it seems unlikely that the Supreme Court would be willing to divorce itself from the Teague doctrine after such a short honeymoon. A more promising approach is to argue that, in the capital sentencing context, the underlying reasons for the doctrine are less persuasive, that the consequences are more dire, and that the Court's own jurisprudence dictates that a doctrine developed in a non-capital context should not be applied to capital cases without consideration of the unique aspects of capital jurisprudence.

In this vein, there are two potential avenues of attack to tlie Teague doctrine's apphication in the capital sentencing context. On one flank is the new rule definition; on the other is the second exception. ${ }^{147}$ Clearly, under the current interpretation, the former offers hittle hope for petitioners. The more "conservative" members of the Court lave made it quite clear tliat their definition of "new" is nearly as broad as Madison Ave-

145. As a side issue, it is interesting to note the current majority's definition of "final." As outhined by Joseph Hoffman, if the avowed purpose of habeas corpus is to deter state court misconduct, then it makes absolutely no sense to use the date of a denial of certiorari as the demarcation of finality. Rather, the date of the highest state court's decision would be more appropriate: Whatever occurs in the intervening period between the state court decision and the filing of a petition for certiorari is beyond the control of the states, and the granting of a habeas petition based on intervening events can have no deterrent effect upon them. See Hoffman, New Vision, supra note 17, at 18485.

146. Tigar, supra note 31 , at 272.

147. As noted earlier, the first exception-whereby a habeas petitioner invoking a new rule will be heard on the merits if the rule in question would place particularized conduct beyond the power of the state to proscribe, or prohibit a particular punishment for a particular class of persons-would be met so infrequently that to rail against its narrowness would be a waste of breath; indeed, it is difficult to imagine a broadened definition of the first exception that would meaningfully assist future capital petitioners while retaining the same basic character as the current formulation. 
nue's, which permits every infinitesimal alteration in the formula for Tide ${ }^{\circledR}$ to qualify for a splashy "NEW AND IMPROVED!!" label. Accordingly, unless the rule in question is so completely determined by prior precedent as to be beyond rational dispute, the Court will label it "new." As a consequence, any brief that advocates a narrower definition of "new" that would allow more habeas cases to be heard would require the Court to reverse itself completely-something it is not likely to do given that a reversal would be an admission of error on the part of the same Justices who recently crafted the doctrine they would be rejectimg. ${ }^{148}$

As a matter of theoretical clarity, the Court is correct in taking an extreme position im defining "new," although it very well could have gravitated to the opposite pole. If "new" was allowed to mean "sorta new" or "kinda new," the cases would possess no consistency, rarely a desirable result. ${ }^{149}$ Therefore, the Court should maintain its view of "new," disadvantageous to petitioners though it may be, both to remove uncertainty and to provide a sharp contrast with opposing views that may later seek to modify or reject it. ${ }^{150}$

The better approach is to urge a modification of the second Teague exception in capital sentencing cases. The flaw in the Supreine Court's current interpretation of the second exception steins froin its disregard of fifteen years of its own jurisprudence that distinguished between capital and non-capital cases when, in Penry, it applied Teague to death cases. A reminder of this fact would provide a good precursor to the suggestion that perhaps the Court was a bit hasty im its formulations, and that perhaps an altered approach is $\mathrm{m}$ order. The last word on the subject coines from Justice Kennedy's opimion in Sawyer, in which the Court inade it abundantly clear that it would not overrule the portion of Penry applying Teague to capital cases. ${ }^{151}$ Sawyer's counsel made a valiant effort to fit his case within the exception, only to be rebuffed:

It is thus not enough under Teague to say that a new rule is aimed at improving the accuracy of trial. More is required. "A rule that qualifies under this exception inust not only inprove accuracy, but also 'alter our understanding of the bedrock procedural elements' essential to the fairness of a proceeding." 152

148. Further, two of the four dissenters in Teague (Justices Brennan and Marshall) have since retired and have been replaced with Justices Souter and Thomas.

149. Except, of course, for attorneys, for whom unclear legal doctrines provide the pretext for substantial numbers of billable hours.

150. Indeed, one might argue that the "newness" inquiry be dropped altogether, as it seems that every rule will be found to be "new" whenever the issue is in question.

151. See Sawyer v. Smith, 110 S. Ct. 2822, 2832 (1990).

152. Id. at 2831 (quoting Teague v. Lane, 489 U.S. 288, 311 (1989)). 
Returning (as scientists and mathematicians say) to first principles, what is required is a reformulation of what are considered the "bedrock" procedural elements essential to the fairness of capital proceedings.

The approach taken by the Supreme Court is essentially to treat the fair proceeding requirement as a simple algebraic sum. Under the Court's reasoning, if all the "bedrock" procedural elements are present and added together, the total is a fair proceeding. Accepting the Court's matheniatical model for the moinent, it nonetheless suffers from two primary flaws in the area of capital sentencing. First, it presumes that the elements of the sum remain constant between capital and non-capital cases. Yet clearly they do not. Capital sentencing review requires a specific inquiry into the presentation and content of aggravating circumstances and mitigating factors at the sentencing phase of the trial, as well as any judicial instructions on how to apply those factors. The basis for Sawyer's claim provides a specific example. No case has yet stated that the mention of the appellate process to the jury in a non-capital case constitutes reversible error; indeed, the reasoning and rationale of Caldwell effectively precludes that result. ${ }^{153}$ But by focusing on the importance of the decision to be made by the jury (death versus life), the Court in Caldwell determined that any implication of a lack of final responsibility for their verdict is impermissible. ${ }^{154}$ Thus, the nature of the prosecutorial arguinent becomes relevant to any review of the resulting death sentence. Had Sawyer been sentenced to life in prison without possibility of parole, that aspect of the prosecutor's argument would not have assisted Sawyer's appeal. Therefore, the pieces that enter into a determination of the fairness of a death sentence are more numerous and more closely scrutinized than are those that enter into the imposition of a term of incarceration.

Second, the Court presumes that the quantum of fairness required is identical between capital and non-capital proceedings. In other words, the Court feels that if the sum of the safeguards provided in non-capital cases ensures fairness, then providing the same elements would do so in capital cases. This iguores the plethora of opinions noted above that draw the qualitative distinction between capital and non-capital cases and the correspondingly disparate levels of review that accompany each. ${ }^{155}$ Clearly, the capital defendant is entitled to a heightened requirement of fairness before he is executed; the problem lies in defining that level. Under the Court's current theory, the level of fairness is defined by the sum of its parts; it possesses no independent value. Working within

153. See Caldwell v. Mississippi, 472 U.S. 320, $328-29$ (1985).

154. See id. at 341.

155. See supra note 141. 
that framework, then, there should be more safeguards provided in criminal cases before their combination will be deemed to have provided a "fair" proceeding.

Therefore, the Court should re-examine both what it considers to be the procedures inherently required in death penalty proceedings, and the number and value of these safeguards necessary to reach the requisite level of fairness. One response to this proposition is that the Court has already performed the first inquiry, rejecting the claims of Butler, Parks, and Sawyer as not imvolving "bedrock procedural elements." One could say that, although the level of fairness in capital cases is indeed higher than that of non-capital proceedings, or that the factors involved are different, the procedural safeguards already in place meet or exceed any required fairness level, and so any further "fine tuning" could not possibly be considered "bedrock." This is the Court's contention in Sawyer: "As we stated in Teague, because the second exception is directed only at new rules essential to the accuracy and fairness of the criminal process, it is unlikely that many such components of basic due process have yet to emerge." 156

Yet the Sawyer analysis disregards the dichotomy between those procedural eleinents essential to all criminal proceedings and those essential to capital sentencing proceedings. The imquiry into the basic procedural requirements for general criminal cases has continued since the development of incorporation doctrime. During this time, the Court has determined, on an issue-by-issue basis, which procedural safeguards are apphicable to the states through the Fourteenth Amendment. This process dates back to at least $1937,{ }^{157}$ and possibly as far back as $1908 .{ }^{158}$ Thus, the Court has had over fifty years to develop the body of general criminal procedural law. In contrast, modern death penalty jurisprudence is less than twenty years old, dating back only to 1972,159 and the area is far from settled. Indeed, the volatile state of capital punishment law is the very reason for the current conundrum: Were the doctrine well-settled, cases such as Arizona v. Roberson, ${ }^{160}$ California v. Brown, ${ }^{161}$ and Caldwell v. Mississippi ${ }^{162}$ would have been decided years ago, and defendants like Butler, Parks, and Sawyer would not have been caught in the middle. The Supreme Court is still deciding what is and is not permissible in capital cases, and so to assert that very few "components of

156. Sawyer, 110 S. Ct. at 2832 (quotation omitted).

157. See Palko v. Connecticut, 302 U.S. 319 (1937).

158. See Twining v. New Jersey, 211 U.S. 78 (1908).

159. See Furman v. Georgia, 408 U.S. 238 (1972).

160. 486 U.S. 675 (1988).

161. 479 U.S. 538 (1987).

162. 472 U.S. 320 (1985). 
basic due process have yet to emerge" in this area ignores the continuing development and refinement of those components.

To adequately address the differences between capital and non-capital proceedings, any flaw that the Court would deem to constitute reversible error should be defined as "bedrock" in capital cases. Any other definition suffers from the incurable infirmity of requiring an ostensibly objective valuation of each procedural protection afforded a capital defendant. Such quantification is utterly impossible. The Court has repeatedly stated that one "bedrock" elenient is the assistance of counsel. Yet if that counsel is wholly meffective, what is the use of his presence? Thus, effective assistance of counsel inust be taken into account. But even the most eloquent attorney is nearly powerless to overconie blatantly prejudicial jury instructions, and so judicial statenients to the jury inust also be considered "bedrock." And on and on it goes. Each procedural protection works in conjunction with every other one, with the result being a fair trial. If the Court has determined that a particular protection is required to ensure fairness, it inakes no sense to inquire whether that section is inore fundamentally necessary than any other; they are all required.

A inore appropriate analogy for the achievement of fairness in capital sentencing cases would be an electric circuit, not a simple sum. Each procedural safeguard is a conductor, connected with each other one, carrying the current that "hights" the "fairness bulb." If one section is renioved, the hight goes out. In soine cases, the broken circuit may be patched through remedial jury instructions or skilled argument by defense counsel, but in those cases fairness will have been ensured. There is no middle ground: Either the light is on or it is off; either a trial is fair or it is not. In Butler, Parks, and Sawyer, the Court seens to iniply that, had the safeguards in question been provided to the petitioners, tlieir respective trials would have been "more fair," but that the trials as they occurred were "fair enough." Yet the sanie could have been said of Roberson and Caldwell, in which the Court vacated the petitioners' death sentences. The Court is fond of saying that a criminal defendant is entitled to "a fair trial, not a perfect one"; ${ }^{163}$ yet, if the safeguards sought by Butler, Parks, and Sawyer were eleinents of perfection ratlier than fairness, how can the holdings of Roberson and Caldwell be explained? They simply cannot. Those cases announced elements lield by the Court to be required to ensure fair capital sentencing procedures; had they been deenied elements of perfection, the Court would not have found them necessary in the first place. Thus, the only distinction between Butler,

163. Delaware v. Van Arsdall, 475 U.S. 673, 681 (1986); accord Ross v. Oklahoma, 487 U.S. 81, 91 (1988); Pope v. Illinois, 481 U.S. 497, 510 n.3 (1987); Rose v. Clark, 478 U.S. 570, 579 (1986). 
Parks, and Sawyer on the one hand, and Roberson and Caldwell on the other, lies in the procedural posture of their cases. Allowing three men to be put to death while two others receive new sentencing hearings, solely because of a fortuity of timing, cannot be condoned. ${ }^{164}$

As the Court refines its death penalty jurisprudence, it is constantly redefinimg the circuit path, sometimes extending it, at other times shunting it (as Justice Scalia's opimion in Walton advocates ${ }^{165}$ ). If a habeas corpus petitioner presents a model of his sentencing hearing that lacks the required components as currently defined by the Court, that hearing was unfair, and the second exception should permit the Court to reach the merits. The only other approach is the one apparently adopted by the Court, which argues that nothing could possibly come along that would qualify as "bedrock." If this is the case, why retain the ostensible exception? It would be of no use to anyone, and would be useless decisional baggage. We must operate on the assumption that the exception would not exist if it were not to be used, and the area of capital sentencing provides a perfect example of when it should be invoked. Thus, any procedural error found to have prejudiced the defendant during the sentencimg phase of a capital case in which the defendant was sentenced to death has affected the fairness of the proceeding in a manner that mandates its reversal.

Opponents of this suggestion will be quick to allege its disadvantages. Supporters of the death penalty have long maintained that a primary failure of the system has been prolonged appeals and reversals on "techuricalities" that limit the deterrent effect of the sanction. Yet there is no evidence that stepped-up execution rates contribute to a reduction in capital crimies. ${ }^{166}$

At a inore pragmatic level, some feel that repeated habeas petitions by death row inmates needlessly delay inevitable executions and waste valuable federal court time and resources. ${ }^{167}$ Yet this concern has been

164. Had the Court recognized the procedural problems in the cases of Butler, Parks, and Sawyer when they were presented on direct review, no problems of retroactivity would have been presented. Because it failed to do so (or because the petitioners' certiorari petitions were inartfully drafted), the Court should admit its mistake and order new sentencing hearings for these petitioners.

165. See supra note 134.

166. See Furman v. Georgia, 408 U.S. 238, 351 (1972) (Marshall, J., concurring) ('Statistics ... show that the deterrent effect of capital punishment is no greater in those communities where executions take place than in other communities. In fact, there is some evidence that imposition of capital punishment may actually encourage crime, rather than deter it.") (footnotes omitted).

167. See, e.g., Report on Habeas Corpus in Capital Cases, 45 Crim. L. Rep. (BNA) 3239, 3239 (1989) (report of the Ad Hoc Committee on Federal Habeas Corpus in Capital Cases of the Judicial Conference of the United States (the "Powell Commission")) ("[O]ur present system of multilayered state and federal appeal and collateral review has led to piecemeal and repetitious litigation, and years of delay between sentencing and a judicial resolution as to whether the sentence was permissible under the law."). 
addressed and resolved by the Court in its most recent Term. In McCleskey v. Zant, ${ }^{168}$ the Court interpreted the abuse of the writ provision ${ }^{169}$ as follows:

When a prisoner files a second or subsequent application, the government bears the burden of pleading abuse of the writ. The government satisfies this burden if, with clarity and particularity, it notes petitioner's prior writ history, identifies the claims that appear for the first time, and alleges that petitioner has abused the writ. The burden to disprove abuse then becomes petitioner's. To excuse his failure to raise the claim earher, he must show cause for failing to raise it and prejudice therefrom as those concepts have been defined in our procedural default decisions. . . . If petitioner cannot show cause, the failure to raise the claim in an earlier petition may nonetheless be excused if he or she can show that a fundamental miscarriage of justice would result from a failure to entertain the claim. ${ }^{170}$

Recognizing this holding's potential impact on retroactivity doctrine, the Court continued: "Apphication of the cause and prejudice standard in the abuse of the writ context does not mitigate the force of Teague $v$. Lane, [489 U.S. 288 (1989),] which prohibits, with certain exceptions, the retroactive apphication of new law to claims raised in federal habeas."171

Yet the new abuse of the writ standard dramatically mitigates the force of the rationale for the Teague doctrine. Now that more petitions may be disposed of at the district court level on abuse grounds, the Court's concerns over an avalanche of successive habeas petitions have been resolved. However, petitioners like Butler, Parks, and Sawyer will (and should) still be heard, because the imposition of death based upon a faulty sentencing procedure would easily satisfy the above "fundamental miscarriage of justice" standard. Although McCleskey drastically reduces the availability of habeas relief to the vast majority of inmates, and may be criticized on that basis, it serves to wholly elimmate the basis for the Teague doctrime in capital sentencing cases.

One unavoidable result of this approacl would be the vacating of numerous death sentences upon discovery of a new procedural requirement. Yet the burden upon the states of such resentencing would not be as onerous as some claim. Only the sentence would be overturned, not the conviction, and so all the evidence from the transcript of the previous trial would be available at the resentencing. The state would simply represent its aggravating circumstances, and the defendant would proffer any mitigating factors. The lapse of time would operate equally against

168. 111 S. Ct. 1454 (1991).

169. 28 U.S.C. $\S 2244$ (1988).

170. McCleskey, $111 \mathrm{~S}$. Ct. at 1470.

171. Id. at $1470-71$. 
both parties, as both prosecution and defense witnesses would tend to die or disappear with equal frequency. And on a human scale, the pecuniary cost of another sentencing hearing pales in comparison with the cost of failing to provide one.

\section{CONCLUSION}

The current Supreme Court doctrine concerning retroactivity eviscerates habeas corpus petitions, reducing them to mere formalities, especially for those sentenced to death and thus in need of the greatest protections. Absent a blatant disregard of settled law by the state courts, the federal courts will now decline to consider any novel arguments offered by the defendant, on the grounds that the petitioner would not be entitled to benefit from a favorable decision. This result is catastrophic in the capital sentencing context. Under the Court's 1989-1990 decisions, a death-row inmate may not assert a procedural error in his case if that activity or omission was not recognized as erroneous before the petitioner's case became final.

The remedy for this manifestly unjust result is to reforinulate the reach of the Teague doctrine's second exception. Because capital cases qualitatively differ from non-capital cases, the reasoning of one is mapplicable to the other. In the capital punishment situation, the evolution of the required procedural safeguards is not yet complete. Until it is, any alteration $\mathrm{m}$ the procedures required durmg capital sentencing should be deemed significant enough to trigger the second exception, thereby allowing habeas petitioners to take advantage of the heightened requirements. Such a policy would not unduly disrupt state criminal systems, and any concern over abuse of the process has already been eliminated by the McCleskey case. Any other course of action is inconsistent with the concept of a civilized society, one that would exact the ultimate punishment only when the accused has been provided with all possible safeguards to prevent an unjust execution. 